\title{
Biomass equations for Brazilian semiarid caatinga plants ${ }^{1}$
}

\author{
Everardo V.S.B. Sampaio ${ }^{2,4}$ and Grécia C. Silva ${ }^{3}$
}

Received: January 01, 2005. Accepted: June 07, 2005

\begin{abstract}
RESUMO - (Equações para estimar a biomassa de plantas da caatinga do semi-árido brasileiro). Equações alométricas foram desenvolvidas para estimar a biomassa aérea viva (B) e a área de projeção da copa (C) de dez espécies da caatinga, com base na altura da planta (H) e/ou do diâmetro do caule ao nível do solo (DNS) ou à altura do peito (DAP). Trinta plantas de cada espécie, cobrindo a faixa usual de diâmetros (3 a $50 \mathrm{~cm}$ ), foram medidas (C, H, DNS, DAP), cortadas na base, separadas em partes, pesadas e subamostradas para determinação da biomassa seca. A densidade (p) da madeira dos caules e galhos maiores foi determinada. B, C, $\mathrm{H}$ e p variaram de 1 a $500 \mathrm{~kg}, 0,2$ a $112 \mathrm{~m}^{2}, 1,3$ a $11,8 \mathrm{~m} \mathrm{e} 0,45$ a $1,03 \mathrm{~g} \mathrm{~cm}^{-3}$. A biomassa das 10 espécies, separadamente ou em conjunto (exceto pela espécie de Cactaceae), foi estimada com alto coeficiente de determinação $\left(\mathrm{R}^{2}\right)$, usando a equação de potência $\left(B=a D N S^{b}\right)$ e DNS, DAP ou combinações de diâmetro, altura e densidade. A melhora com a multiplicação de DNS ou DAP por H e/ou p foi pequena. A equação de DAP (válida até $30 \mathrm{~cm}$ ) para o conjunto das nove espécies teve $a=0,173$ e $b=2,295$, semelhantes aos valores das médias das equações encontradas na literatura, mas um pouco abaixo dos referidos para vegetação tropical úmida. A projeção das copas foi significativamente relacionada com diâmetros do caule, alturas e biomassas.
\end{abstract}

Palavras-chave: diâmetro do caule, altura, área da copa, densidade da madeira

\begin{abstract}
Biomass equations for Brazilian semiarid caatinga plants). Allometric equations to estimate total aboveground alive biomass (B) or crown projection area (C) of ten caatinga species based on plant height (H) and/or stem diameter at ground level (DGL) or at breast height $(\mathrm{DBH})$ were developed. Thirty plants of each species, covering the common range of stem diameters $(3 \mathrm{to} 50 \mathrm{~cm})$, were measured (C, H, DGL, DBH), cut at the base, separated into parts, weighted and subsampled to determine dry biomass. Wood density (p) of the stem and the largest branches was determined. B, C, $\mathrm{H}$ and p ranged from 1 to $500 \mathrm{~kg}, 0.2$ to $112 \mathrm{~m}^{2}, 1.3$ to $11.8 \mathrm{~m}$, and 0.45 to $1.03 \mathrm{~g} \mathrm{~cm}^{-3}$. Biomass of all 10 species, separately or together (excluding one cactus species), could be estimated with high coefficients of determination $\left(\mathrm{R}^{2}\right)$ using the power equation $\left(\mathrm{B}=\mathrm{aDGL}{ }^{\mathrm{b}}\right)$ and $\mathrm{DGL}, \mathrm{DBH}, \mathrm{H}$ or combinations of diameter, height and density. Improvement by multiplying $\mathrm{H}$ and/or $\mathrm{p}$ to DGL or DBH was small. The mixed-species equation based only on DBH (valid up to $30 \mathrm{~cm}$ ) had $a=0.173$ and $b=2.295$, similar to averages of these parameters found in the literature but slightly lower than most of those for humid tropical vegetation. Crown area was significantly related to diameter, height and biomass.
\end{abstract}

Key words: stem diameter, height, crown area, wood density

\section{Introduction}

The standing alive aboveground biomass of a vegetation is an important biological information. It has been used for several purposes, including those related to wood production, net primary productivity, nutrient cycling and the recent interest in $\mathrm{CO}_{2}$ dynamics and the greenhouse effect (Ter-Mikaelian \& Korzukhin 1997; Nelson et al. 1999; Keller et al. 2001). Therefore, different methods have been devised to estimate this biomass. The use of allometric equations based on plant characteristics is one of these methods (Ter-Mikaelian \& Korzukhin 1997; Zianis \&
Mencuccini 2004), having, among other advantages, that of being non-destructive.

Allometric equations have been determined for many plant species in different biomes, both temperate (Ter-Mikaelian \& Korzukhin 1997) and tropical (Haase \& Haase 1995; Kumar et al. 1998; Nelson et al. 1999; Keller et al. 2001) but semiarid tropical biomes have received little attention (Okello et al. 2001; Samba et al. 2001). Even scarcer are published data about species of semi-arid Northeast Brazil, a picture worsened by the fact that most of the published material has a rather restricted circulation (PNUD/ FAO/IBAMA 1992).

\footnotetext{
1 Part of the Doctor Thesis of the second Author

2 Universidade Federal de Pernambuco, Av. Prof. Luís Freire 1000, CEP 50740-540, Recife, PE, Brazil

3 Universidade Estadual da Bahia, Departamento de Tecnologia e Ciências Sociais, Av. Edgard Chastinet s/n, São Geraldo, CEP 48900-000, Juazeiro, BA, Brazil

4 Corresponding Author: esampaio@ufpe.br
} 
Caatinga vegetation, due to the irregular and limited rainfall of the semiarid region, rarely reaches heights above $20 \mathrm{~m}$ and is dominated by small trees and shrubs. The native vegetation is used to produce fuel wood and is part of the slash and burn itinerant agriculture cycle (Sampaio 1995). Therefore, most of the area is in some stage of regrowth after being clearcut. This mosaic of vegetation stages has been described in some detail by phytosociological studies (Sampaio 1996), which provide accurate data on plant measurements for more than a hundred species in dozens of sites. Allometric equations could use these measurements to estimate biomass under these different situations.

The objective of this paper is to derive biomass estimation models for ten of the most important caatinga species.

\section{Material and methods}

Nine of the species were selected among those with the widest distribution within caatinga and also with the highest basal area in most of the sites (Sampaio 1996). The high basal areas resulted from a combination of high plant densities with moderate individual stem diameter or large stem diameter with low to average densities. The first group included mostly small trees or shrubs: Aspidosperma pyrifolium Mart., Caesalpinia pyramidalis Tul., Croton sonderianus Muell. Arg., Jatropha mollissima (Pohl.) Baill., Maytenus rigida Mart. and Mimosa hostilis Benth. The second group included the common large trees of caatinga: Anadenanthera macrocarpa (Benth.) Brenan, Myracrodruon urundeuva Fr. All. and Schinopsis glabra (Engl.) F.A. Barkly \& T. Mey. A tenth species, Cereus jamacaru DC., was selected to represent the tall Cactaceae of caatinga and is quite abundant in many locations.

Each species was represented by 30 individuals, chosen to cover the common range of stem diameters found in different locations. The largest diameters were underrepresented because they refer to exceptional trees, difficult to find and not recommended to cut. The minimum diameter was $3 \mathrm{~cm}$ just above ground level, established as the standard for caatinga phytosociological studies (Rodal et al. 1992). The individuals were selected at random in two different locations, searching for the first ones that fitted the sizes still missing to cover the diameter range but excluding those with any sign of having been cut or of any clear abnormality (burning, vine strangling, very inclined stem growth due to heavy shading or dead leaning tree, etc). Exclusion of these abnormal plants may reduce variability but the effect should be small because they comprise a small proportion of plants in the whole community.

The two sites were in Santaluz $\left(39^{\circ} 22^{\prime} \mathrm{W}\right.$ and $\left.11^{\circ} 15^{\prime} \mathrm{S}\right)$ and Petrolina (40 $30^{\prime} \mathrm{W}$ and $\left.9^{\circ} 23^{\prime} \mathrm{S}\right)$ municipalities, Bahia and Pernambuco States, respectively, within the regional zone defined as 'Depressão Sertaneja', the most typical of the Brazilian semiarid region. Both have average temperatures around $26^{\circ} \mathrm{C}$, with little monthly variation, and annual evapotranspiration of 1,500-2,000 $\mathrm{mm}$. Annual rainfall in the first site averages $709 \mathrm{~mm}$ and in the second one averages $430 \mathrm{~mm}$, both concentrated in 3-5 months, with high variation from year to year. Soils are a complex mosaic of Lytholic, Red Yellow Podzolic and Non-calcic Brown soils, from low to average fertility.

Stem perimeter at the base and $1.3 \mathrm{~m}$ above, the length of the longest axis of the crown projection area and that of its longest orthogonal axis were measured. Perimeters were transformed to diameters at ground level (DGL) and at breast height (DBH), assuming a circular shape, and also to basal area at ground level (AGL) and at breast height (ABH). When branching occurred below measuring height, the area of each branch was calculated and all the areas added to give a single basal area, from which a single diameter was calculated. The crown projection area was calculated assuming an elliptical shape. After these measurements, the plant was cut at the base in a way that the crown fell on a canvas lying in the ground. Total plant height (H) was then measured, including the stump.

The plant was then separated into parts (stem, large and small branches and leaves) which were weighed fresh and sampled for dry matter determination after oven heating at $60^{\circ} \mathrm{C}$ until constant weight. Sampling included disks for wood density determination taken from the stem and the largest branches. The weight of the stump was calculated from its volume and density and added to the dry weight of the plant. Since most of the species shed their leaves during the dry season, the work was conducted in the second half of the rainy season, when plants had what seemed to be a full crown.

Models relating biomass to plant measurements were devised using single variables and also different combinations of plant measurements, either summed or multiplied (heights versus diameters or areas). Fitting of the data to five types of equations (linear, quadratic, logarithmic, exponential and power function) was 
performed using common statistical programs and evaluating the fitness based on the coefficient of determination $\left(\mathrm{R}^{2}\right)$ and also on the square root of the error mean square (standard error), because of the different number of variables in some equations. Only the best fitting equations (all with $\mathrm{p}<0.01$ ) are shown.

\section{Results and discussion}

Plant characteristics - The dry biomass of plants of all ten species had a wide range, in some cases increasing by more than a hundred fold from the smallest to the largest plant, from less than 1 to more than $500 \mathrm{~kg}$ (Tab. 1). The range of all other plant characteristics was narrower, with height going from 1.3 to $11.8 \mathrm{~m}$, crown projection area from 0.2 to $112 \mathrm{~m}^{2}$ and stem diameter at ground level (DGL) from the minimum, established as $3 \mathrm{~cm}$, up to $50 \mathrm{~cm}$. These ranges were similar to those in caatinga as a whole (Alcoforado Filho et al. 2003), with a few exceptions. For one of the trees, A. macrocarpa, no plant was found larger than $22 \mathrm{~cm}$ DGL but it is common to find larger individuals in many areas. On the other hand, plants of C. pyramidalis, reaching $50 \mathrm{~cm}$ in diameter, were larger than usual and some of the selected ones had hollow trunks. We decided not to exclude these, although they added to unexplained variability, because they were not many and represent real cases. Larger plants of most of the species can be found at well preserved caatinga sites, particularly those located in more humid areas, where they can reach up to $60 \mathrm{~cm}$ in diameter and $19 \mathrm{~m}$ height (Alcoforado Filho et al. 2003; Pereira et al. 2003). However, the abundance of these larger plants is always low. In the review of Alcoforado Filho et al. (2003), all studied caatinga sites, except two, had less than 20 plant ha ${ }^{-1}$ larger than $42 \mathrm{~cm}$ in DGL (less than $1 \%$ of all plants $>3 \mathrm{~cm}$ DGL).

The average wood density of the nine caatinga species $\left(0.87 \mathrm{~g} \mathrm{~cm}^{-3}\right)$, excluding C. jamacaru, was higher than plot averages or averages for a large number of species in humid forests, which range from 0.6 to $0.7 \mathrm{~g} \mathrm{~cm}^{-3}$ (Brown et al. 1995; Ketterings et al. 2001; Nogueira et al. 2005). Wood in dry areas, where growth is slow, can attain high densities (Holbrook et al. 1995), but several caatinga species have low densities (as J. mollissima) and the average we obtained certainly reflects the choice of species. The caatinga plant densities, determined by drying at $60^{\circ} \mathrm{C}$, may be slightly higher (ca. 2\%) than if they were dried at the standard $103{ }^{\circ} \mathrm{C}$ (Nogueira et al. 2005). No data was found on density of $C$. jamacaru to compare to our results.

Estimation of species biomass - The biomass of all ten species could be estimated with high coefficients of determination using different plant measures. In general, the best fit (Tab. 2) was obtained using the diameter at ground level and the power equation (biomass $=\mathrm{aDGL}^{\mathrm{b}}$, in $\mathrm{kg}$ and $\mathrm{cm}$, respectively). For some species, the fit was almost as good using a quadratic or an exponential equation (equations not shown) but only in the case of Jatropha mollissima both were better than the power equation, especially the quadratic one (biomass $=12.97+0.3516 \mathrm{DGL}-$ 3.978DGL ${ }^{2}, \mathrm{R}^{2}=0.86$ ).

Using the diameter at breast height (DBH), rather than DGL, is more common in other vegetation types and the fit was as good with this variable as with DGL (Tab. 2), an expected result considering that both were highly correlated $\left(\mathrm{R}^{2}=0.94\right)$. DGL was included because it has been recommended in phytosociological studies of caatinga (Rodal et al. 1992) and its more

Table 1. Range of values for plant characteristics of the 10 selected Brazilian semiarid caatinga species used in the study. DGL $=$ stem diameter at base level (minimum was set at $3 \mathrm{~cm}$ ); Density = wood density with bark of large branches; $\max =\operatorname{maximum}$ and $\min =\operatorname{minimum}$.

\begin{tabular}{|c|c|c|c|c|c|c|c|c|}
\hline \multirow[t]{2}{*}{ Species } & \multirow{2}{*}{$\begin{array}{c}\mathrm{DGL}(\mathrm{cm}) \\
\max \end{array}$} & \multicolumn{2}{|c|}{ Biomass (kg) } & \multicolumn{2}{|c|}{ Height (m) } & \multicolumn{2}{|c|}{ Crown area $\left(\mathrm{m}^{2}\right)$} & \multirow{2}{*}{$\begin{array}{c}\text { Density }\left(\mathrm{g} \mathrm{cm}^{-3}\right) \\
\text { average }\end{array}$} \\
\hline & & $\min$ & $\max$ & $\min$ & $\max$ & $\min$ & $\max$ & \\
\hline A. pyrifolium & 23.5 & 3.1 & 70 & 3.4 & 7.2 & 1.6 & 22 & 0.96 \\
\hline C. sonderianus & 12.3 & 0.6 & 17 & 2.5 & 6.3 & 0.6 & 13 & 0.77 \\
\hline J. mollissima & 15.6 & 0.8 & 44 & 1.5 & 5.7 & 0.2 & 24 & 0.47 \\
\hline C. pyramidalis & 50.3 & 4.5 & 485 & 2.9 & 10 & 3.3 & 70 & 0.92 \\
\hline M. rigida & 25.8 & 1.4 & 205 & 2.8 & 7.6 & 0.1 & 29 & 0.91 \\
\hline M. hostilis & 27.2 & 2.8 & 185 & 2.8 & 8.0 & 3.3 & 55 & 1.03 \\
\hline A. macrocarpa & 21.6 & 1.4 & 113 & 3.1 & 8.4 & 3.5 & 39 & 0.96 \\
\hline M. urundeuva & 32.5 & 1.2 & 382 & 2.8 & 11.8 & 0.7 & 112 & 0.97 \\
\hline S. glabra & 35.0 & 1.8 & 536 & 3.7 & 11.6 & 1.3 & 70 & 0.83 \\
\hline C. jamacaru & 23.0 & 0.6 & 50 & 1.3 & 7.5 & - & - & 0.45 \\
\hline
\end{tabular}


Table 2. Allometric equations to calculate oven-dry aboveground plant biomass ( $\mathrm{kg}$ ) of Brazilian semiarid caatinga species, based on stem diameter at ground level (DGL, cm), stem diameter at breast height $(\mathrm{DBH}, \mathrm{cm})$, stem area at ground level $\left(\mathrm{AGL}, \mathrm{cm}^{2}\right), \mathrm{stem}^{\mathrm{area}}$ at breast height $\left(\mathrm{ABH}, \mathrm{cm}^{2}\right)$, total plant height $(\mathrm{H}, \mathrm{m})$ and wood density $(\mathrm{p})$. All with $\mathrm{p}<0.01$.

\begin{tabular}{|c|c|c|c|c|}
\hline Species & Equations with DGL & $\mathrm{R}^{2}$ & Equations with DBH & $\mathrm{R}^{2}$ \\
\hline A. pyrifolium & $0.2455 * \mathrm{DGL}^{1.7726}$ & 0.9265 & $0.3675 * \mathrm{DBH}^{1.8355}$ & 0.8527 \\
\hline C. sonderianus & $0.1482 * \mathrm{DGL}^{1.8741}$ & 0.8266 & $0.3569 * \mathrm{DBH}^{1.8565}$ & 0.8414 \\
\hline J. mollissima & $0.0689 * \mathrm{DGL}^{2.0557}$ & 0.7668 & $0.1970 * \mathrm{DBH}^{1.8145}$ & 0.8288 \\
\hline C.pyramidalis & $0.2804 * \mathrm{DGL}^{1.9274}$ & 0.9015 & $0.2365 * \mathrm{DBH}^{2.1928}$ & 0.8198 \\
\hline M. rigida & $0.1142 * \mathrm{DGL}^{2.2543}$ & 0.9605 & $0.3460 * \mathrm{DBH}^{2.0231}$ & 0.9501 \\
\hline M. hostilis & $0.1064 * \mathrm{DGL}^{2.2907}$ & 0.9699 & $0.3127 * \mathrm{DBH}^{2.1183}$ & 0.9594 \\
\hline A. macrocarpa & $0.1395 * \mathrm{DGL}^{2.1579}$ & 0.9232 & $0.2482 * \mathrm{DBH}^{2.1628}$ & 0.9372 \\
\hline M. urundeuva & $0.0596 * \mathrm{DGL}^{2.4878}$ & 0.9739 & $0.1397 * \mathrm{DBH}^{2.4659}$ & 0.9821 \\
\hline S. glabra & $0.1452 * \mathrm{DGL}^{2.2137}$ & 0.9674 & $0.2274 * \mathrm{DBH}^{2.2710}$ & 0.9742 \\
\hline C. jamacaru & $0.0268 * \mathrm{DGL}^{2.3440}$ & 0.9658 & $0.0010 * \mathrm{DBH}^{3.2327}$ & 0.7005 \\
\hline Small species (top 3) & $0.0644 * \mathrm{DGL}^{2.1999}$ & 0.8467 & $0.2627 * \mathrm{DBH}^{1.9010}$ & 0.8189 \\
\hline Large species (next 6) & $0.0871 * \mathrm{DGL}^{2.3366}$ & 0.9505 & $0.2368 * \mathrm{DBH}^{2.2219}$ & 0.9455 \\
\hline All but $C$. jamacaru & $0.0644 * \mathrm{DGL}^{2.3948}$ & 0.9207 & $0.1730 * \mathrm{DBH}^{2.2950}$ & 0.9184 \\
\hline (") & $0.0886 * \mathrm{AGL}^{1.1974}$ & 0.9207 & $0.2283 * \mathrm{ABH}^{1.1475}$ & 0.9184 \\
\hline “ & $0.0292 *(\mathrm{DGL} * \mathrm{H})^{1.6371}$ & 0.9382 & $0.0612 *\left(\mathrm{DBH}^{*} \mathrm{H}\right)^{1.5811}$ & 0.9478 \\
\hline “ & $0.0527 *(\mathrm{AGL} * \mathrm{H})^{0.9707}$ & 0.9397 & $0.1085^{*}(\mathrm{ABH} * \mathrm{H})^{0.9497}$ & 0.9494 \\
\hline “ & $0.0412 *(\mathrm{AGL} * \mathrm{H})$ & 0.9098 & $0.0780\left(\mathrm{ABH}^{*} \mathrm{H}\right)$ & 0.9203 \\
\hline “ & $0.0832 *(\mathrm{AGL} * \mathrm{H} * \mathrm{p})^{0.9224}$ & 0.9495 & $0.1648 *\left(\mathrm{ABH}^{*} \mathrm{H}^{*} \mathrm{p}\right)^{0.9023}$ & 0.9573 \\
\hline
\end{tabular}

easily measured in multitrunked plants. The coefficients of equations with DGL or with DBH varied considerably but, for all species, DGL could be substituted by DBH multiplied by 1.3335 , with relatively small changes in the estimated values of biomass.

The power equation has been the most frequently used to estimate biomass based on stem diameter, representing plants from different environments, from tropical to temperate and from small to large size (Ter-Mikaelian \& Korzukhin 1997; Zianis \& Mencuccini 2004), including species of special growth forms, such as palms, bromeliads and Cecropia sciadophylla (Hay et al. 1982; Hay 1982). No such equation was found for Cactaceae but our equation for $C$. jamacaru had parameters similar to those of the other caatinga species but with low coefficients of determination. This may result from the peculiar format of these columnar cacti but the absence of comparable data prevents further discussion.

The exponential parameters $(b)$ of the DGL and the DBH power equations were not very different for each species and for all of them varied within a relatively narrow range around the value 2 (1.77 to 2.49), except for $C$. jamacaru. Based on this parameter and on their general characteristics, the species could be separated in three groups: 1) C. jamacaru; 2) Aspidosperma pyrifolium, Croton sonderianus, and Jatropha mollissima, species with lower biomass; and 3) the other six species, with higher biomass, for equal diameters, than the previous group. In general, species in the group of smaller plants had $b$ lower than 2 while those of the larger plants were above 2 . The linear parameter $(a)$ had a larger variation $(0.001$ to 0.36$)$ than the exponential one and in a certain way compensated for this last one. For instance, the lowest $a$ matched the highest $b$ of the C. jamacaru DBH equation.

Common equations for groups of species - The similarity of $b$ in the equations of each species might indicate that a common equation could be calculated for each of the two groups and even for the group of the nine species, excluding $C$. jamacaru (Tab. 2). However, one must be aware of the fact that any small change in the exponential parameter has a large effect on the estimate of the biomass, especially of plants with large diameters. The curves of the two groups show increasing divergence as stem diameters become larger (Fig. 1), in spite of the small differences in both equation parameters, especially $b$ (2.1999 and 2.3366). However, the differences in the curves are somewhat misleading because they were extrapolated to diameter sizes that the small species did not reach in this study. All three small species had plants with less than $25 \mathrm{~cm}$ DGL (Tab. 1) and their biomasses correspond to points that are not very far from the curve for the six larger species. Therefore, the general equation for all nine species had a high coefficient of 


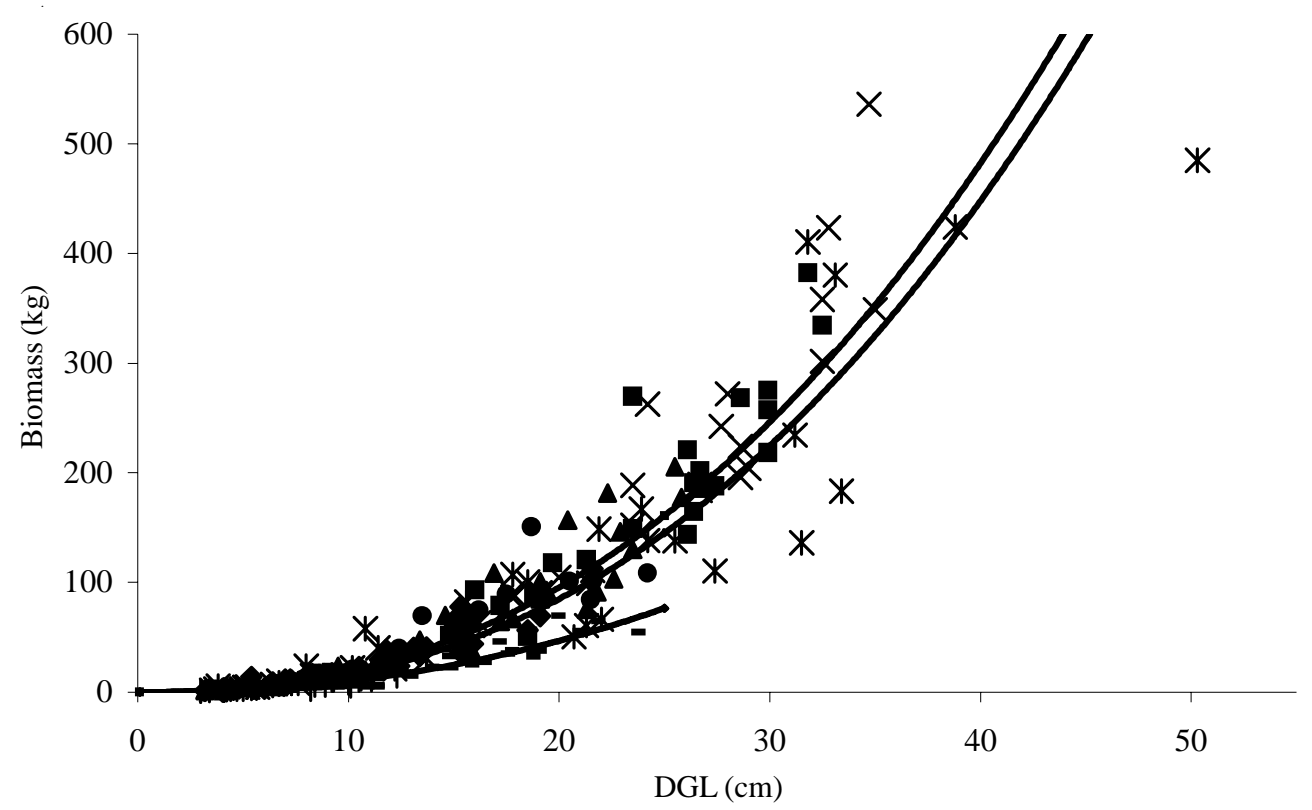

Figure 1. Total plant biomass as a function of stem diameter at ground level (DGL) for 9 Brazilian caatinga species (Anadenanthera macrocarpa (Benth.) Brenan, am; Myracrodruon urundeuva Fr. All., mu; Maytenus rigida Mart., mr; Schinopsis glabra (Engl.) F.A. Barkly \& T. Mey, sg; Caesalpinia pyramidalis Tul., cp; Mimosa hostilis Benth., mh; Croton sonderianus Muell. Arg., cs; Aspidosperma pyrifolium Mart., ap; and Jatropha mollissima (Pohl.) Baill., jm). Fit of power equation for all species (middle curve), the first six (top curve), and the last three (lower curve). $\bullet=\mathrm{am} ; \boldsymbol{\square}=\mathrm{um} ; \boldsymbol{\Delta}=\mathrm{mr} ; \times=\mathrm{sg} ; *=\mathrm{cp} ; \bullet=\mathrm{mh} ;+=\mathrm{cs} ; \boldsymbol{\bullet}=\mathrm{ap} ; \boldsymbol{-}=\mathrm{jm}$.

determination $\left(\mathrm{R}^{2}=0.92\right.$, for 270 plants $)$, both based on DGL or DBH.

The equations for each species can be useful for population studies but most of the studies requiring the estimation of biomass are more interested in all the species of a given area. Caatinga, as other tropical vegetation, has a large number of shrub and tree species, totaling several hundreds, although most of them are represented in any one area by a few individuals and a few species are abundant almost everywhere (Sampaio 1996). Generating a specific equation for every species is a tremendous task and applying all these equations in ample surveys is also very time and effort consuming. Therefore, most authors try to obtain general equations valid for vegetation types that cover large areas (Ketterings et al. 2001; Zianis \& Mencuccini 2004). The high coefficient of determination in our general equation indicates that the equation can be used for estimation of caatinga biomass. However, validation of this estimation by actual weighing of all plants in different plots is recommended as a next step in this research line. It is also recommended to restrict estimates to sites where species not included in our general equation comprise small proportions of the total basal area.

Extrapolation of the equations to plants larger than $30 \mathrm{~cm} \mathrm{DBH}$ is not advisable. In case they are used, in the absence of a more appropriate equation, to calculate total biomass of a site, one must consider that large errors can be introduced in the site biomass, even if the large plants are only a few (Araújo et al. 1999; Nelson et al. 1999), although Keller et al. (2001) stated that improved allometric relations for very large trees would result in only minimal improvements of total site biomass estimates. Under representation of the largest plants is a common problem in the development of allometric equations (Brown et al. 1989; 1995; Chambers et al. 2001) and it is difficult to solve because there is a strong, justified resistance to cut these trees. In fact, even the upper part of our sampled range (> $25 \mathrm{~cm} \mathrm{DBH}$ ) was not represented by many individuals and estimation for them is less precise than for smaller plants.

The two parameters of the power equation can vary much, particularly if they are obtained from a set of data with a small range of values for the diameter. In this case, a lower value of $b$ can be compensated by a higher value of $a$ and vice versa. It has been shown that the two parameters are inversely related (Zianis \& Mencuccini 2004) and, calculating for the equations of the ten caatinga species, they had a linear negative relation, although with low coefficients of determination (0.75 with DBH and 0.58 with DGL). When the data set has a larger range of diameters and biomasses, usually 
the linear increment of $a$ cannot compensate the decrease in the exponential parameter. In spite of these variations, the $b$ value, in general, oscillates around 2 and for larger ranges lies between 2 and 3 (Ketterings et al. 2001; Zianis \& Mencuccini 2004).

Exponential parameters of most species with values around 2 suggest that the power equation using DGL or $\mathrm{DBH}$ could be substituted by a linear equation using their respective basal areas (AGL and ABH). However, for all species, the biomass was still better related to the basal area by power equations than by linear ones (not shown). The same occurred for equations of all nine species together and the value of the parameter $b$ above 1 indicated that the biomass increased more than proportionately as the basal area increased (Tab. 1). This probably occurred because of a concomitant increase in plant height.

Biomass of all species, except $C$. jamacaru, was significantly related to total plant height $(\mathrm{H}, \mathrm{m})$ and the best fit was obtained using the power equation (biomass $=0.0509 \mathrm{H}^{3.777}$ ) but the coefficient of determination $\left(\mathrm{R}^{2}=0.74\right)$ was not as high as those obtained with DGL or DBH. Incorporating plant height to the equations with DGL, DBH or their respective areas resulted in higher coefficients of determination than using any single variable but the improvement in estimation was small (Tab. 2). This probably comes from the fact that diameters and height were related, although the coefficients of determination were not very high $\left(\mathrm{H}=1.6086 \mathrm{DGL}^{0.4684}, \mathrm{R}^{2}=0.65\right.$ and $\left.\mathrm{H}=2.0175 \mathrm{DBH}^{0.4308}, \mathrm{R}^{2}=0.59\right)$. The basal areas (AGL or $\mathrm{ABH}$ ) multiplied by height, which express stem volume, were best related to biomass by a power equation but could also be related by a linear equation crossing the origin (Table 2) and although the coefficients of determination were lower they were still quite good $\left(\mathrm{R}^{2}=0.91\right)$. These linear equations provide easy estimates of biomass.

Incorporating height to the equations relating biomass and stem diameter has been shown to improve estimation for plants in vegetation of many different regions but many authors concluded, as we did, that the improvement was small and that it was not worthwhile the effort of determining height in the field in any large set of plants (Haase \& Haase 1995; Rayachhetry et al. 2001). The difficulty of determining height, mainly in tall, closed canopy vegetation, explains the general scarcity of data of this variable.

The addition of wood density to any of the above equations did not improve or improved only slightly and non-significantly the estimation of biomass of each species. Improvements were better for the equations of the two groups and even better for the nine species together, although the increases in the coefficient of determination were small (Tab. 2).

Comparisons of equation parameters - Ketterings et al. (2001) postulated that the parameter $b$ in the equation relating biomass and stem diameter $\left(\mathrm{B}=\mathrm{aDBH}{ }^{\mathrm{b}}\right)$ would be composed of the value 2 , corresponding to the transformation of diameter in area, plus the value of $c$ coming from the power equation relating height and stem diameter $\left(\mathrm{H}=\mathrm{kDBH}^{\mathrm{c}}\right)$ and that the parameter $a$ would be composed of a constant $r$, characteristic of a site, multiplied by the average wood density (p) at the site $(\mathrm{a}=\mathrm{rp})$. They based their postulation on the assumption that biomass and volume $(\mathrm{V}$, calculated by multiplying stem basal area by plant height) are linearly related. Their data for 29 trees in a secondary forest at Indonesia support their assumption: $b$ was almost equal to $2+c(2.59$ and $2+0.62)$. In the caatinga, the difference was greater $(b=2.295 ; 2+c=2+0.4308)$ and biomass and volume (calculated by $\mathrm{ABH} \times \mathrm{H}$ ) were better related by a power equation than by a linear one, as discussed before. Therefore, the assumption of a linear relation does not hold very well. In fact, the assumption of Ketterings et al. (2001) is just a special case of a more general relation. Considering that $\mathrm{B}=\mathrm{eV}^{\mathrm{g}}$ and that $\mathrm{V}$ corresponds to a simple geometric model (a cylinder, for instance), the equation becomes $\mathrm{B}=\mathrm{e}\left[(\pi / 4) \mathrm{DBH}^{2}\right]^{\mathrm{g}} \times\left[\mathrm{kDBH}^{\mathrm{c}}\right]^{\mathrm{g}}$ or, rearranging, $\mathrm{B}=\mathrm{e}(\pi \mathrm{k} / 4)^{\mathrm{g}} \times \mathrm{DBH}^{\mathrm{g}(2+c)}$. Therefore, $b$ is only equal to $2+c$ if $g$ is equal to 1 . This was not the case for the caatinga plants, which had a $g$ below 1 (Tab. 2) but it was almost so for the Indonesian plants. The discrepancy could result from several causes (potbelly or hollow trunks, irregular stem cross section, fissured bark), the most important probably being different branching patterns. The stem volume is certainly overestimated if calculated as a cylinder based on its area and the plant height and this extra volume may be more or less compensated by the branch volume. The subject deserves further attention but this has been limited by the absence of branching pattern data.

Another consequence of considering the general relation represented by $\mathrm{B}=\mathrm{e}(\pi \mathrm{k} / 4)^{\mathrm{g}} \times \mathrm{DBH}^{\mathrm{g}(2+\mathrm{c})}$ instead of $\mathrm{B}=\mathrm{aDBH}^{\mathrm{b}}$ is that $a$ has to incorporate all the transformations of the rearranging of the equations and it is not equal to $e$, even if $g$ is made equal to 1 . This verification does not invalidate the assumption made by Ketterings et al. (2001) of $a=r p$ but it means that all transformations are accumulated in $r$. For the 
caatinga species, the average wood density was $0.87 \mathrm{~g} \mathrm{~cm}^{-3}$ and $r$ of the DBH equation would be 0.199 . Both the density and $r$ are higher than the values for the Indonesian species (Ketterings et al. 2001) and this is only possible because the parameter $a$ of the $\mathrm{DBH}$ equation is much higher in the caatinga equation (0.173 versus 0.066$)$. It is important to mention that the density corresponds to the average of all nine species, each with equal number of plants, but a true relation would have to consider the average density of the community being surveyed, as also recognized by the above authors.

Zianis \& Mencuccini (2004) discussed the estimation of $b$ based on: 1) fractal properties; 2) theoretical principles; 3 ) an empirical value calculated as the average of 279 equations found in the literature; and 4) a method they proposed in which $b$ is calculated from data of a few measured small plants and the best fitting of equations already found in the literature. The fractal and theoretical value (2.67), besides the disadvantage of being fixed for all situations, gave worse results than the empirical one, when they tested against some available data sets. Their method of small plants worked well in these sets but not for caatinga plants because the new equation underestimated biomass of larger plants. The empirical value (2.3679) was significantly lower than the fractal one and closer to our result for caatinga (2.295). They did not report the average $a$ value, which we calculated, from their
Appendix A, as 0.147 (slightly lower than 0.173 found for caatinga). The similarity of values and the compensation of higher $b$ but lower $a$ results in estimated biomasses quite close to those of caatinga species (Tab. 3). This suggests that the biomasses of plants with the same DBH but belonging to different vegetation types are not as different as the differences in the parameters of their equations would seem to indicate. In other words, the range of biomasses for an equal $\mathrm{DBH}$ is more limited than the range of the parameters $a$ and $b$. This somewhat limited range is probably established by mechanical considerations.

Calculating biomasses for diameters up to $50 \mathrm{~cm}$ from the equations reviewed by Zianis \& Mencuccini (2004), we found both higher and lower values than those of caatinga. Those based on selected plants that had a narrow range of diameters, usually small plants, were the most discrepant and this probably resulted more from the extrapolation than from a true difference in plant structure. Unfortunately, for several of the equations the range of diameters were not informed. On the other hand, a few equations obtained from a wide range of diameters estimated higher biomasses than those of caatinga. A few of them belong to humid tropical species, indicating that they really have more biomass for equal stem diameters than caatinga species, probably because they are taller. Some of the equations for these tropical species, together with a few for large group of species are shown in Tab. 3.

Table 3. Characteristics of power equations to calculate biomass of plants (kg) based on diameter at breast height (DBH, cm). Biomass refers to the estimates with DBH equal to 10 and $50 \mathrm{~cm}$; DBH range $(\mathrm{cm})$ to that of the original study. Data obtained from Zianis \& Mencuccini (2004), except for that of caatinga. Equations were listed by order of biomass of $50 \mathrm{~cm} \mathrm{DBH}$.

\begin{tabular}{|c|c|c|c|c|c|c|}
\hline \multirow[t]{2}{*}{ Plants } & \multicolumn{2}{|c|}{ Parameters } & \multicolumn{2}{|c|}{ Biomass } & \multirow{2}{*}{$\begin{array}{l}\mathrm{DBH} \\
\text { range }\end{array}$} & \multirow[t]{2}{*}{ Authors } \\
\hline & $\mathrm{a}$ & $\mathrm{b}$ & 10 & 50 & & \\
\hline Tropical & 0.1043 & 2.660 & 48 & 3448 & na & Brown 1997 \\
\hline Tropical & 0.1043 & 2.600 & 42 & 2727 & na & Brown 1997 \\
\hline Tropical & 0.0680 & 2.650 & 35 & 2480 & na & Araújo et al. 1999 \\
\hline Tropical & 0.1394 & 2.480 & 42 & 2279 & na & Overman et al. 1994 \\
\hline USA & 0.0580 & 2.910 & 21 & 2268 & $11-57$ & Martin et al. 1998 \\
\hline Tropical & 0.0920 & 2.560 & 33 & 2048 & na & Brown 1997 \\
\hline Tropical & 0.0880 & 2.570 & 33 & 2046 & na & Brown 1997 \\
\hline All USA & 0.0566 & 2.663 & 26 & 1893 & $3-63$ & Martin et al. 1998 \\
\hline Tropical & 0.1357 & 2.413 & 35 & 1706 & $1-29$ & Nelson et al. 1999 \\
\hline Tropical & 0.0661 & 2.591 & 26 & 1668 & na & Ketterings et al. 2001 \\
\hline Average & 0.1470 & 2.368 & 34 & 1549 & na & Zianis \& Mencuccini 2004 \\
\hline Australia & 0.2350 & 2.236 & 41 & 1481 & na & Snowdon et al. 2000 \\
\hline Tropical & 0.1636 & 2.320 & 34 & 1430 & na & Brown 1997 \\
\hline Tropical & 0.1353 & 2.360 & 31 & 1383 & na & Edwards \& Grubb1977 \\
\hline Caatinga & 0.1730 & 2.295 & 34 & 1371 & $2-50$ & This work \\
\hline Tropical & 0.0898 & 2.410 & 23 & 1116 & na & Ovington 1957 \\
\hline
\end{tabular}


Height and crown projection area - The coefficients of determination of the power equations relating diameter and height for the ten different caatinga species were significant but not very high (0.59-0.65). In semi-arid Senegal, Samba et al. (2001) found a high coefficient (0.99) for the equation $\mathrm{H}=0.76 \mathrm{DBH}^{0.74}$. Several other equations types have been suggested to represent this relation (Fang \& Bailey 1998) and we tried them on the caatinga data. None of them improved estimation but it is interesting to note that in their equation 18 $\left(\mathrm{H}=\mathrm{a}+\mathrm{b}\left(1-\mathrm{e}^{-\mathrm{c}(\mathrm{DBH}-\mathrm{DBH} \text { min })}\right)\right.$, parameters $a$ and $b$ resulted in values not much above those actually found in the field. The value of parameter $a$, minimum height, was $3.4 \mathrm{~m}$, higher than the $2.3 \mathrm{~m}$ found in the field, while $a+b$, maximum height, was $13.5 \mathrm{~m}$, also higher than the true $11.8 \mathrm{~m}$.

DGL and DBH could be used to predict crown projection area of the nine different caatinga species (excluding the Cactaceae) but the relations were not as close as those for total biomass, with coefficients of determination of $0.72\left(\right.$ crown $\left.=0.1939 \mathrm{DGL}^{1.6311}\right)$ and $0.73\left(\right.$ crown $\left.=0.362 \mathrm{DBH}^{1.5763}\right)$. Adding plant height to the diameters or to the areas increased the coefficients of determination but only to a small extent and, as discussed before, may not justify the extra field work in obtaining height data. Crown area was also related to total biomass $\left(\mathrm{B}=1.7098 \mathrm{CA}^{1.1175}, \mathrm{R}^{2}=0,74\right)$ but the coefficient was not high. Samba et al. (2001) found better coefficients relating DBH and crown length and diameter. Our equations for crown area provide an information seldom available in caatinga areas and that is important in determining the openness of the vegetation. This openness has been frequently used in the classification of different caatinga types (Sampaio 1996) and it is related to the amount of herb production, an important variable in the common use of caatinga as native pasture.

\section{Aknowledgments}

Research partially financed by Conselho Nacional de Desenvolvimento Científico e Tecnológico (CNPq) and InterAmerican Institute for Global Change Research (IAI).

\section{References}

Alcoforado Filho, F.G.; Sampaio, E.V.S.B. \& Rodal, M.J.N. 2003. Florística e fitossociologia de um remanescente de vegetação caducifólia arbórea em Caruaru, Pernambuco. Acta Botanica Brasilica 17: 287-303.
Araújo, T.M.; Higuchi, N. \& Carvalho Junior, J.A. 1999. Comparison of formulae for biomass content determination in a tropical rain forest site in the state of Pará, Brazil. Forest Ecology and Management 117: 43-52.

Brown, I.F.; Martinelli, L.A.; Thomas, W.W.; Moreira, M.Z.; Ferreira, C.A. \& Victoria, R.A. 1995. Uncertainty in the biomass of Amazonia forests: an example from Rondônia, Brazil. Forest Ecology and Management 75: 175-189.

Brown, S.; Gillespie, A.J.R. \& Lugo, A.E. 1989. Biomass estimation methods for tropical forests with applications to forest inventory data. Forest Science 35: 881-902.

Brown, S. 1997. Estimating biomass and biomass change of tropical forests. (Forest Resources Assessment Publication. Forestry Papers 134). Rome, FAO.

Chambers, J.K.; Santos, J.; Ribeiro, R.J. \& Higuchi, N. 2001. Tree damage, allometric relationships, and above-ground net primary production in central Amazon forest. Forest Ecology and Management 152: 73-84.

Edwards, P.J. \& Grubb, P.J. 1977. Studies of mineral cycling in a montane rain forest in New Guinea. I. The distribution of organic matter in the vegetation and soil. Journal of Ecology 65: 943-971.

Fang, Z. \& Bailey, R.L. 1998. Height-diameter models for tropical forests on Hainan Island in Southern China. Forest Ecology and Management 110: 315-327.

Haase, R. \& Haase, P. 1995. Above-ground biomass estimates for invasive trees and shrubs in the Pantanal of Mato Grosso, Brazil. Forest Ecology and Management 73: 29-35.

Hay, J.D. 1982. Estimativas da biomassa de indivíduos jovens de Cecropia sciadophylla (Moraceae). Acta Amazonica 12: 33-39.

Hay, J.D.; Henriques, R.P.B. \& Costa, S.R.A. 1982. Uma avaliação preliminar da possibilidade de usar equações de regressão para estimativas da biomassa da restinga. Revista Brasileira de Botânica 5: 33-36.

Holbrook, N.M.; Whitbeck, J.L. \& Mooney, H.A. 1995. Drought response of neotropical dry forest trees. Pp. 243276. In: S.H. Bullock; H.A. Mooney \& E. Medina (eds.). Seasonally dry tropical forests. Cambridge, Cambridge University Press.

Keller, M.; Palace, M. \& Hurtt, G. 2001. Biomass estimation in the Tapajos National Forest, Brazil: examination of sampling and allometric uncertainties. Forest Ecology and Management 154: 371-382.

Ketterings, Q.M.; Coe, R.; Noordwijk, M.; Ambagau, Y. \& Palm, C.A. 2001. Reducing uncertainty in the use of allometric biomass equations for predicting above-ground tree biomass in mixed secondary forests. Forest Ecology and Management 146: 199-209.

Kumar, M.; George, S.J.; Jamaludheen, V. \& Suresh, T.K. 1998. Comparison of biomass production, tree allometry and nutrient use efficiency of multipurpose trees grown in woodlot and silvopastoral experiments in Kerala, India. Forest Ecology and Management 112: 145-163.

Martin, J.G.; Kloppel, B.D.; Schaefer, T.L.; Kimbler, D.L. \& Mcnulty, S.G. 1998. Aboveground biomass and nitrogen allocation of ten deciduous southern Appalachian tree species. Canadian Journal of Forest Research 28: 1648-1659. 
Nelson, B.W.; Mesquita, R.; Pereira, J.L.G.; Souza, S.G.A.; Batista, G.T. \& Couto, L.C. 1999. Allometric regressions for improved estimate of secondary forest biomass in the central Amazon. Forest Ecology and Management 117: 149-167.

Nogueira, E.M.; Nelson, B.W. \& Fearnside, P.M. 2005. Wood density in dense forest in central Amazonia, Brazil. Forest Ecology and Management 208: 261-286.

Okello, B.D.; O'Connor, T.G. \& Young, T.P. 2001. Growth, biomass estimates, and charcoal production of Acacia drepanolobium in Laikipia, Kenya. Forest Ecology and Management 142: 143-153.

Overman, J.P.M.; Witte, H.J.L. \& Saldarriaga, J.G. 1994. Evaluation of regression models for above-ground biomass determination in Amazon rainforest. Journal of Tropical Ecology 10: 218-297.

Ovington, J.D. 1957. Dry-matter production by Pinus sylvestris L. Annals of Botany 21: 287-314.

Pereira, I.M.; Andrade, L.A.; Sampaio, E.V.S.B. \& Barbosa, M.R.V. 2003. Use-history effects on structure and flora of caatinga. Biotropica 35: 154-165.

PNUD/FAO/IBAMA. 1992. Plano de manejo florestal para a região do Seridó do Rio Grande do Norte. Natal, PNUD/ FAO/IBAMA.

Rayachhetry, M.B.; Van, T.K.; Center, T.D. \& Laroche, F. 2001. Dry weight estimation of the aboveground components of Melaleuca quinquenervia trees in Southern Florida. Forest Ecology and Management 142: 281-290.
Rodal, M.J.N.; Sampaio, E.V.S.B. \& Figueiredo, M.A. 1992 Manual sobre métodos de estudo florístico e fitossociológico - ecossistema caatinga. Brasília, Sociedade Botânica do Brasil.

Samba, S.A.N.; Camiré, C. \& Margolis, H.A. 2001. Allometry and rainfall interception of Cordyla pinnata in a semi-arid agroforestry parkland, Senegal. Forest Ecology and Management 154: 277-288.

Sampaio, E.V.S.B. 1995. Overview of the Brazilian caatinga. Pp. 35-63. In: S.H. Bullock; H.A. Mooney \& E. Medina (eds.). Seasonally dry tropical forests. Cambridge, Cambridge University Press.

Sampaio, E.V.S.B. 1996. Fitossociologia. Pp. 203-230. In: E.V.S.B. Sampaio; S.J. Mayo \& M.R.V. Barbosa (eds.). Pesquisa botânica nordestina: progresso e perspectivas. Recife, Sociedade Botânica do Brasil/Seção Regional de Pernambuco.

Snowdon, P.; Eamus, D.; Gibbons, P.; Khanna, P.K.; Keith, H.; Raison, R.J. \& Kirschbaum, M.U.F. 2000. Synthesis of allometrics, review of root biomass and design of future woody biomass sampling strategies. Camberra, Australian Greenhouse Office. (National Carbon Accounting System Technical Report 17).

Ter-Mikaelian, M.T. \& Korzukhin, M.D. 1997. Biomass equations for sixty-five North American tree species. Forest Ecology and Management 97: 1-24.

Zianis, D. \& Mencuccini, M. 2004. On simplifying allometric analysis of forest biomass. Forest Ecology and Management 187: $311-332$. 
